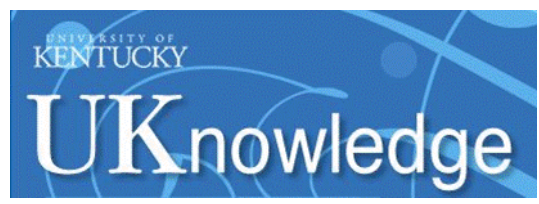

University of Kentucky

UKnowledge

$6-6-2008$

\title{
Taking the Sting Out of Multiple Format Serials Displays
}

\author{
Marsha Seamans \\ University of Kentucky, marsha.seamans@uky.edu \\ Nancy Lewis \\ University of Kentucky
}

Follow this and additional works at: https://uknowledge.uky.edu/libraries_present

Part of the Library and Information Science Commons

Right click to open a feedback form in a new tab to let us know how this document benefits you.

\section{Repository Citation}

Seamans, Marsha and Lewis, Nancy, "Taking the Sting Out of Multiple Format Serials Displays" (2008). Library Presentations. 66.

https://uknowledge.uky.edu/libraries_present/66

This Presentation is brought to you for free and open access by the University of Kentucky Libraries at UKnowledge. It has been accepted for inclusion in Library Presentations by an authorized administrator of UKnowledge. For more information, please contact UKnowledge@lsv.uky.edu. 


\section{Taking the Sting Out of Multiple Format Serial Displays}

Marsha Seamans

$$
\text { \& }
$$

Nancy Lewis

University of Kentucky

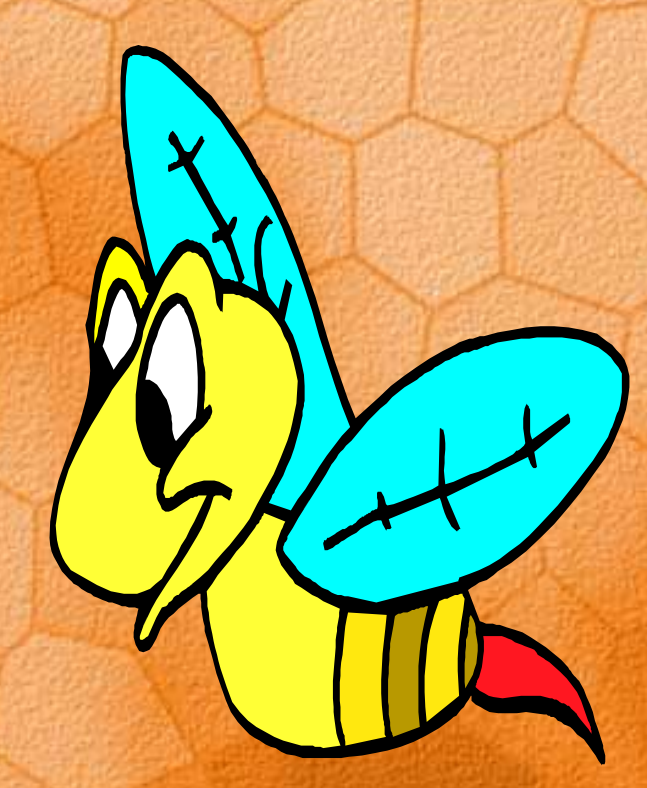




\section{Providing Access to E-Journals}

- "The mission of cataloging is to provide good quality access to selected resources for our users by organizing all these materials consistently in the OPAC"

-Duranceau, "Cataloging remote access electronic serials" The Balance Point (Winter 1995)

- "Bibliographic control is the organization of library materials to facilitate discovery, management, identification, and access"

- On the record : report of the Library of Congress Working Group on the Future of Bibliographic Control (January 9, 2008) 


\section{In the beginning ...}

- Reference librarians/subject specialists

- Individual A-Z list

- EJAG Database (FileMaker Pro) 
Browse by Journal Title

$\underline{A} \underline{B} \underline{C} \underline{D} \underline{E} \underline{F}$

$\underline{G} \underline{H} \underline{I} \underline{J} \underline{K} \underline{L}$

$\underline{\mathrm{M}} \underline{\mathrm{N}} \underline{\mathrm{O}} \underline{\mathrm{P}} \underline{\mathrm{Q}} \underline{\mathrm{R}}$

$\underline{\mathrm{S}} \underline{\mathrm{I}} \underline{\mathrm{U}} \underline{\mathrm{V}} \underline{\mathrm{W}} \underline{\mathrm{X}}$

$\underline{Y-Z}$

\section{(9) Search}

Database Name: UK Electronic Journals

Please see the help file for field tips.

Keyword Search:

\section{Field Search:}

Journal Name: abacus

Hint: type ==journal in the Journal Name box to find titles beginning with "Journal"

URL:

Aggregator: - No Selection

Print subscription: $\bigcirc$ Yes $\odot$ No $\odot$ N/A

Subscription type: $\square$ Paid subscription |

$\Gamma$ Free with print

$\Gamma$ Free NOTIS Number

- Trial

$\Gamma$ Trial

Г Elect

$\ulcorner$ Aggr

Restrictions: $\square$ No el

Г Must

$\Gamma$ Restr

$\Gamma$ Rest

Copyright 2000 . versity of Kentuck

Registered: $\odot$ Yes

Publisher:

Proxy: $\circ$ Yes

Fund Code:
Return: 20 records at a time.

[Records will be sorted by title.] 


\section{JSTOR Experiment (2001)}

- Single record approach

- URL to EJAG

- 909 JSTOR

- 530 Also available via the Internet.

- Add a holding record for the e-version 


\section{Vendor \& Batch loads}

- 2003

- PCl, EbscoHost, LION, Emerald

- 2004

- Project Muse, JSTOR, NewsBank, Cambridge Press, DOAJ, Sage

Records added in separate Owning Library to allow for easy deletion \& reload and to prevent accidental attachment of Acquisitions or holdings information 


\section{Multiple Records}

- JSTOR Again!

- 3 URLS

- To the title

- To EJAG

- To Off-Campus Proxy instructions

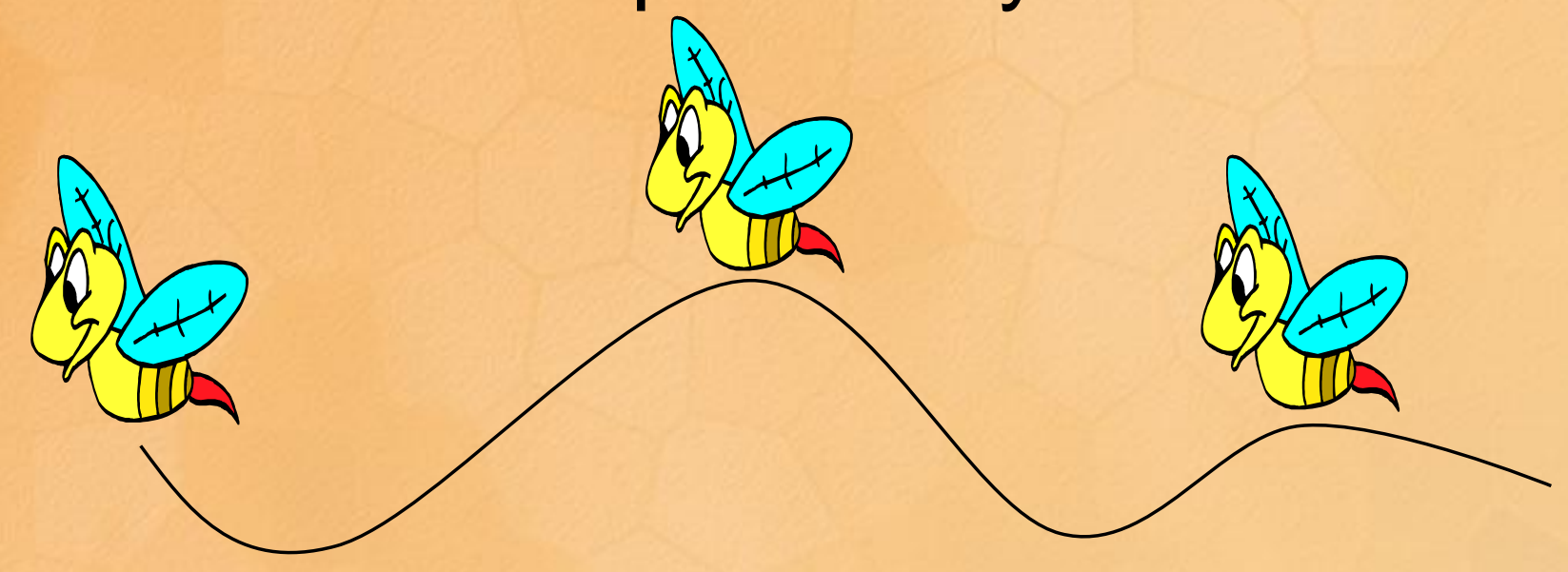




\section{Multiple records ... sometimes}

Bibliographic Policy and Procedure (2003/2004)

- When all the formats represent the same copy of a serial such as backfiles or replacements in another format for a paper original, then only one bibliographic record with separate holdings (MFHD) records would remain the standard practice. [GAPS]

- For records from aggregator databases, separate records for each aggregator will be maintained, although both records represent an electronic resource. This will allow unique coverage to be maintained and keeping the records separate will reduce maintenance efforts as these records are updated. [AGGREGATOR SPECIFIC]

- If a serial is superceded by an electronic resource, the 856 for the electronic resource may be added to the serial record as appropriate. [SINGLE] 


\section{"Aggregator neutral"}

- "Policy of creating a separate record for each aggregation became confusing and hard to maintain"--CONSER

- More and more print cancelled in favor of electronic

- Redundant coverage in packages

- Firmly moved to separate records for print and electronic versions of Serials 


\section{SFX}

- First, along with EJAG - Later, replacing EJAG

- SFX button

\section{Get Text GUR}

- 856 link: $\ddagger u$

http://sfx.uky.edu:3210/sfxlcl3?url ver=Z39.882004\&url ctx fmt=info:ofi/fmt:kev:mtx:ctx\&ctx ver

$=$ Z39.88-2004\&ctx enc=info:ofi/enc:UTF8\&rfr id=info:sid/sfxit.com:kbmanager\&sfx.ignore date threshold=1\&rft.issn=XXXXXXXXX $\neq z<$ img src="http://www.uky.edu/Libraries/images/uksfxbut ton.gif" border $=0>$ 


\section{Bib linking}

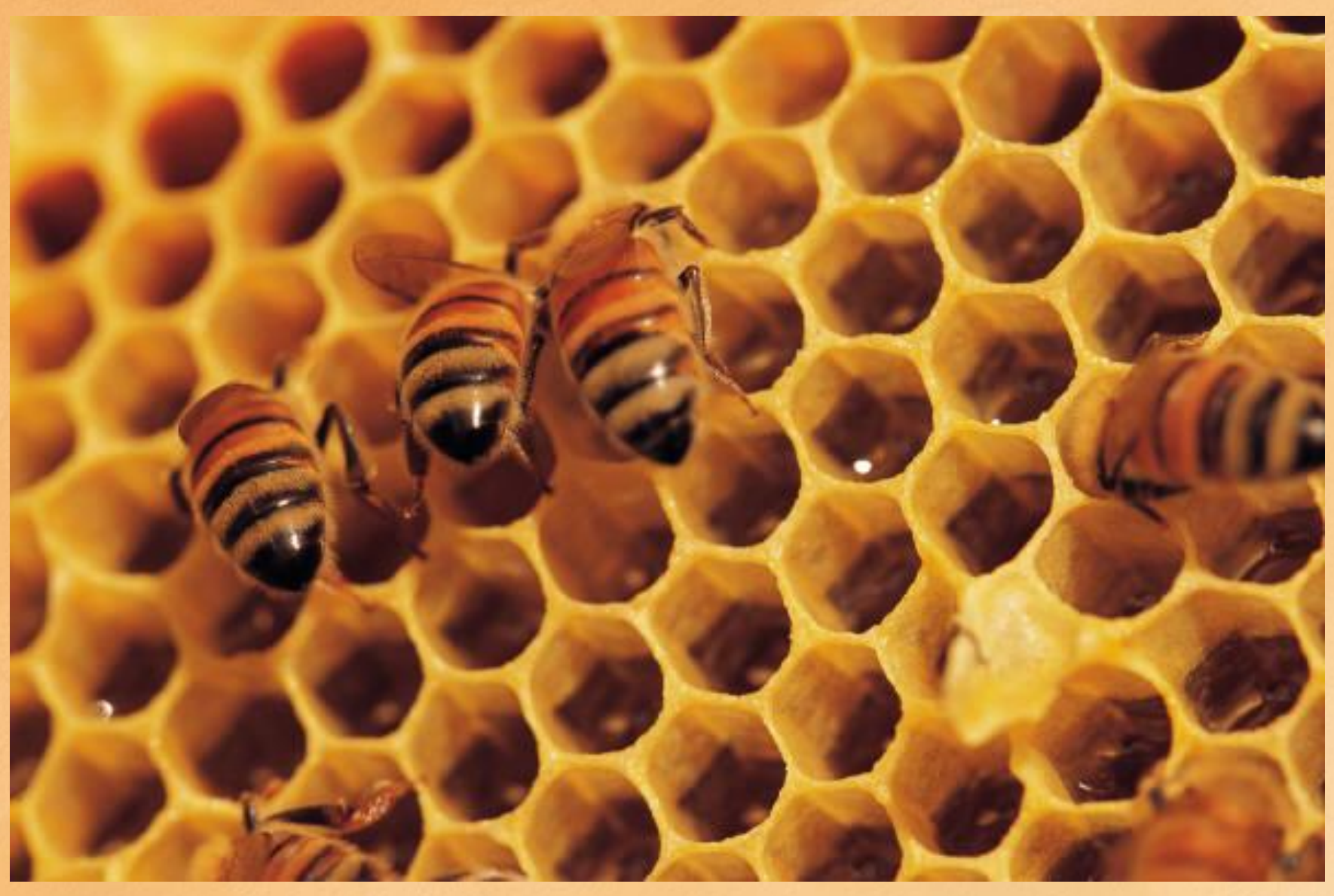




\section{Bib Linking - What is it?}

- Bib linking creates hyperlinks between separate related catalog records such as print and electronic serial versions with the same content.

- Each hyperlink is created at the time of the catalog search, it is not persistent.

- No backend maintenance required to maintain the links, though some initial cleanup of some of the records is needed. 


\section{What's it look like?}

\section{Print display with Bib Link to e-journal display}

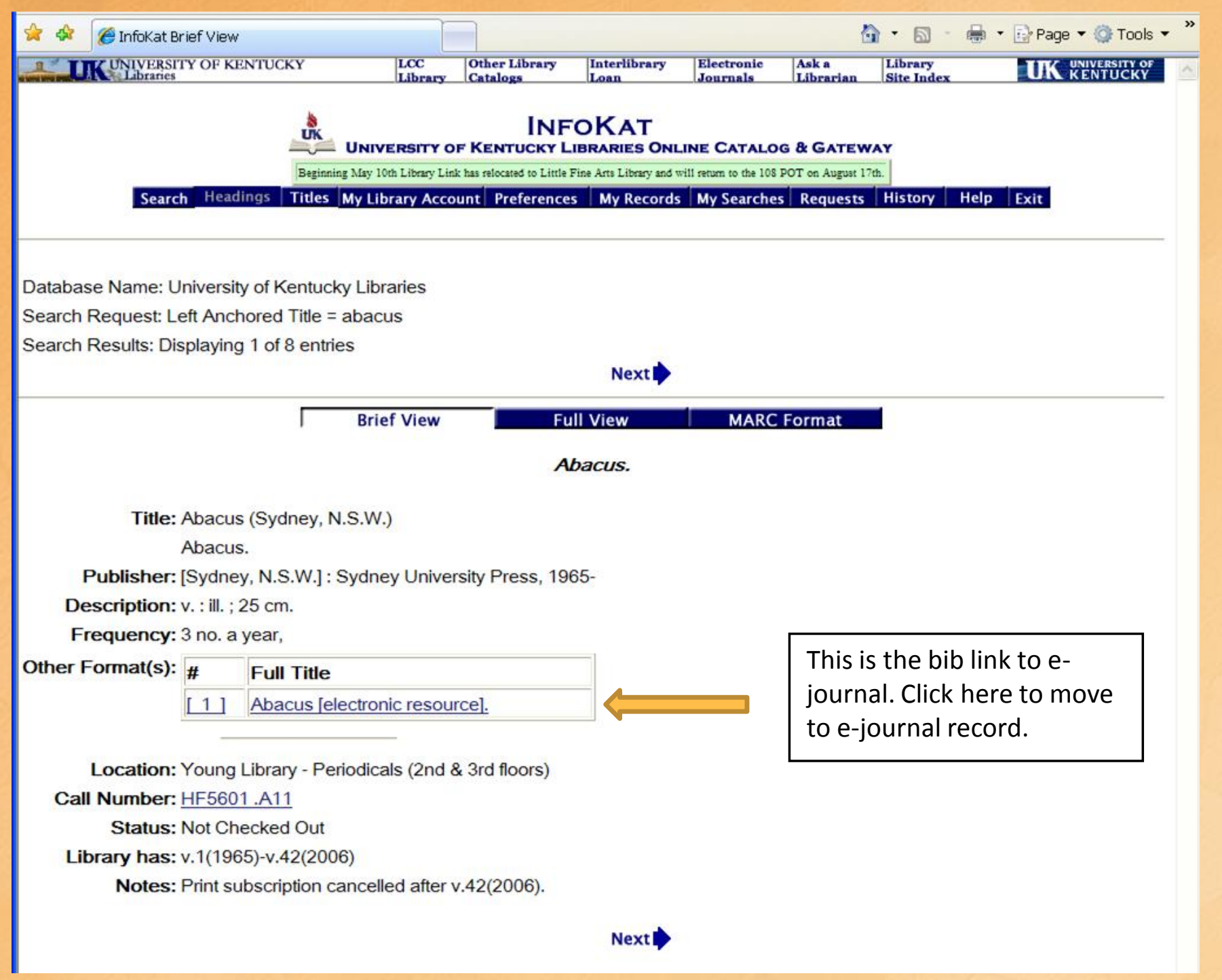




\section{What's it look like?}

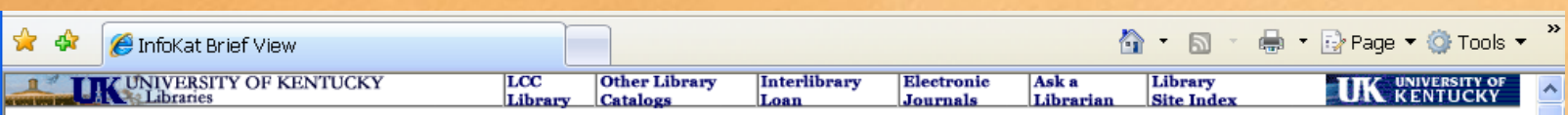

Display for e-journal display with SFX button \& Bib Link to Print display

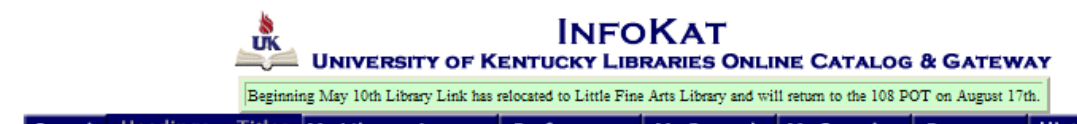

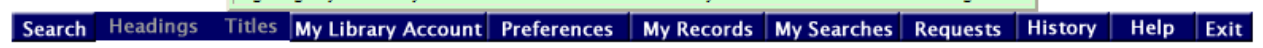

Database Name: University of Kentucky Libraries

Search Request: Left Anchored Title = abacus

Search Results: Displaying 1 of 1 entries

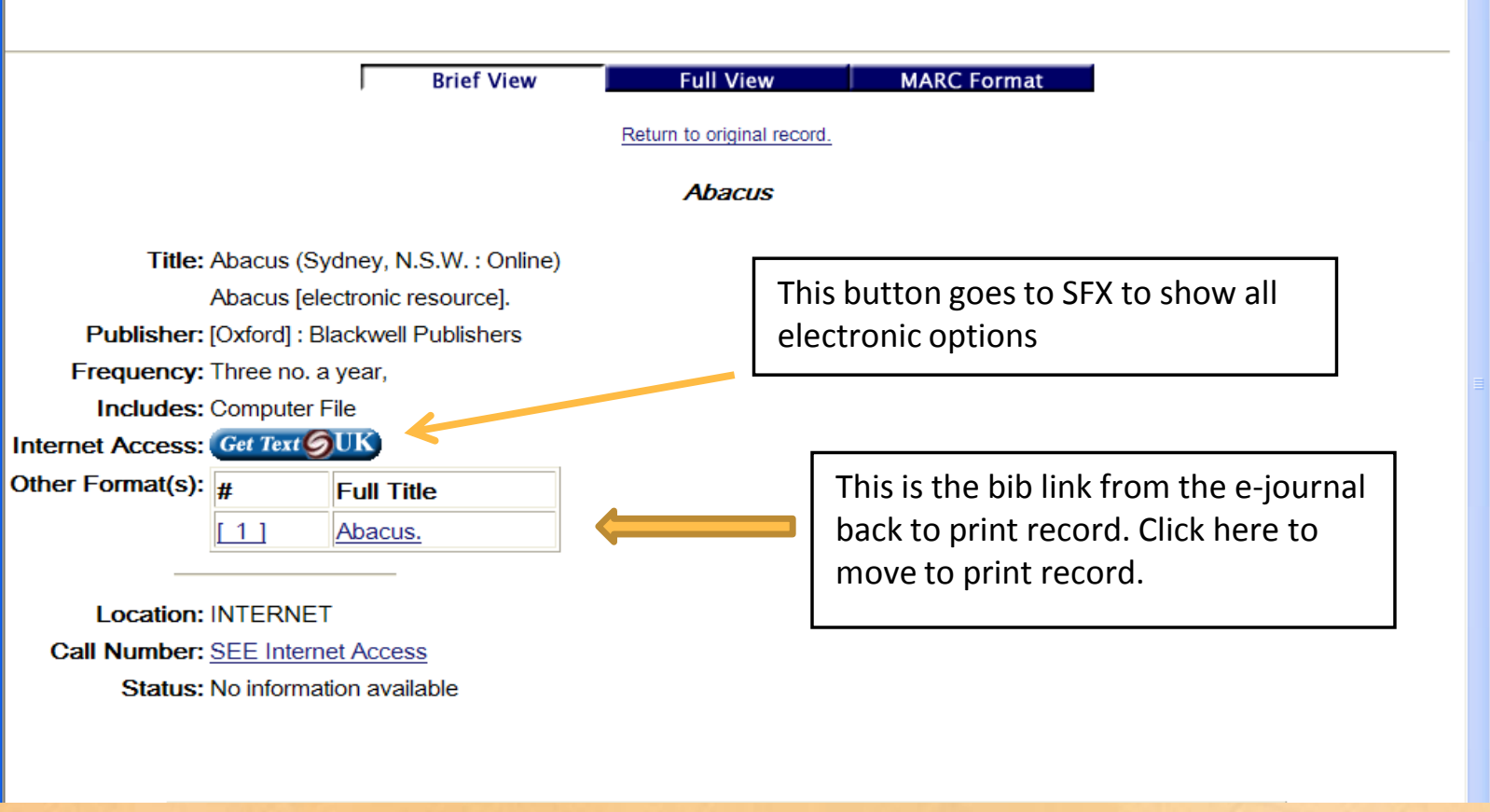




\section{SFX \\ Display}

SFX by Ex Libris Inc. for the University of Kentucky Libraries - Windo

(9) 9 http://sfx.uky.edu:3210/sfxlc13?url_ver=239.88-20048url_ct__fmt=info:ofi/fmt:kev:mtx:ctx\&c:

File Edit View Favorites Tools Help

th the SFX by Ex Libris Inc, for the University of Ken...

\section{University of Kentucky Libraries}

\section{Get TextGUK Services for this record}

Source: Abacus [0001-3072]

Electronic Full Text Option(s)

Electronic full text from EBSCOhost Business Source Premier

Available from 1965

Most recent 1 year(s) not available

Electronic full text from Synergy Blackwell Premium

Available from 1997

Catalog Information

Check for holdings in the UK Libraries' catalog, InfoKat.

Web Service

FAQ about the UK Get Text service

Need help? Ask A UK Librarian 


\section{Electronic}

\section{resource}

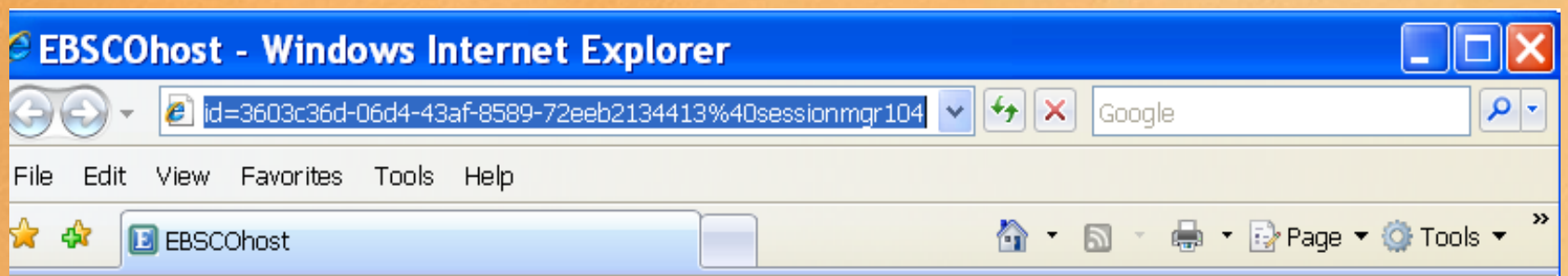

New EBSCOhost 2.0 Coming July 2008 Learn More

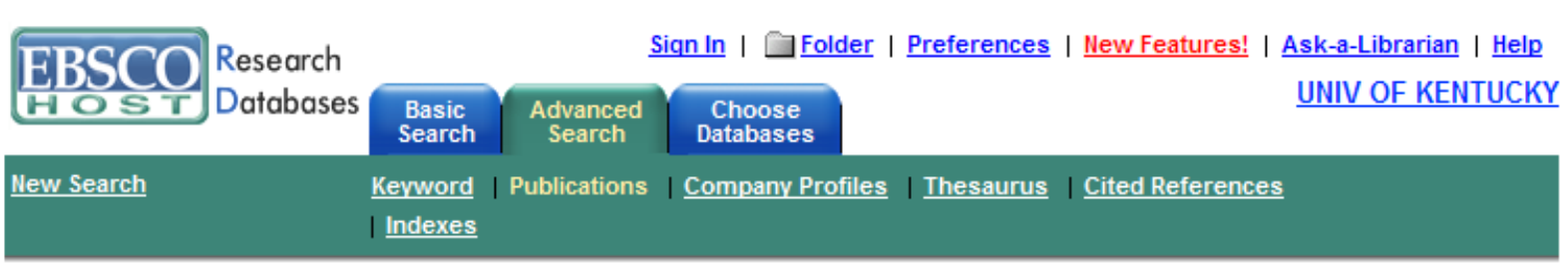

Database: Business Source Premier Publications

Publications

Golder is empty.

Previous Record | Next Record

Publication Details For "Abacus"

$$
\text { Title: Abacus }
$$

ISSN: $0001-3072$

Publisher Blackwell Publishing Limited

Information: 9600 Garsington Road

Oxford OX4 2DQ

United Kingdom

Bibliographic $09 / 01 / 1965$ to present

Records:

Full Text: $\quad 09 / 01 / 1965$ to present (with a 12 Month delay)

"Full text delay due to publisher restrictions ("embargo")

Link to this http://search.ebscohost.com/login.aspx?direct

Publication: =true \&db=buh\&jid=AUB\&site=ehost-live

Publication Type: Academic Journal

Subjects: Accounting \& Tax; Banking, Finance \& Insurance; Business
Search within this publication | Journal Alert

All Issues

$+2008$

$+2007$

$+2006$

$+2005$

$+2004$

$+2003$

$+2002$

$+2001$

$+2000$

$+1999$

$+1998$

$+1997$

$+1996$

$+1995$

$+1994$

$+1993$

$+1992$

$+1991$

$+1990$ 


\section{Princeton model}

- Bell, Joyce. "Bib Linking print and electronic records." Presentation at EndUsers 2006.

- Provided the how to manual.

- Princeton focused primarily on ISSN and ISBN links 


\section{Upon further investigation ...}

- Additional

programming was

needed to implement

this into our catalog.

- We obtained a quote to index four of our MARC fields to set up the relationships in both our training database and our live catalog.
- Another quote was obtained that would provide our patrons the ability to move between all related records such as earlier and later serial titles, and records with a parent/ child relationship. 


\section{Integrated Library Systems \\ Committee Proposal}

- Bib linking would link our print and electronic materials to make things clearer to our patrons in the OPAC display by providing seamless transport between the print and electronic versions.

- October, 2006, we submitted a Request of funds for Bib linking print and electronic records 


\section{How did we do it?}

We obtained programming to create new left- anchored indexes in our Voyager database for:

- Additional physical form entry 776 field

- Iw Record control number

- |x ISSN

- Nonspecific relationship entry 787 field

- Iw Record control number

- Bid ID Voyager record number 001 field 


\section{Voyager Systems Administrator}

Set up profiles to define relationships between certain fields in the bibliographic records

- 022 a to $776 \mid x$

- 035 |a to 776 |w

- Voyager Bib ID to 787 |w 


\section{How does it works?}

- Voyager checks each retrieved record for the presence of one of the established relationships and then Voyager checks for a record which meets the matching part of the relationship.

- Link is created as each record is retrieved

- There is no permanent link between the two records 


\section{Characteristics}

- Relationships determined by the bib

content

- Very flexible

- Reciprocal/Multiple links

- e-journal to print / print to e-journal

- Print to both microfilm and electronic/ Microfilm to both print and electronic/ Electronic to both print and microfilm

- One-sided links

- Distinct title in series to a parent serial 


\section{Marc records for Print and}

\section{Electronic}
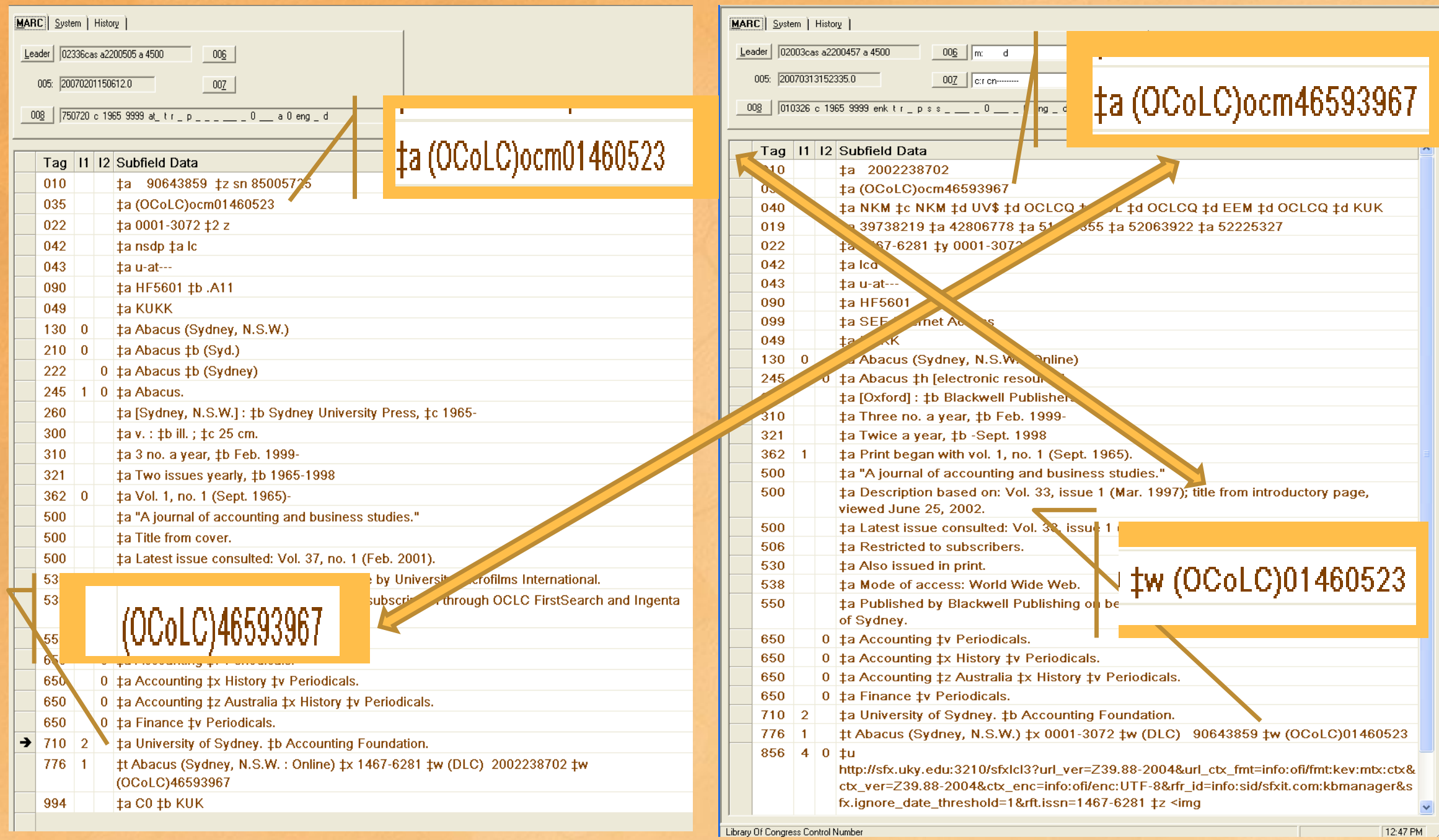


\section{When Voyager retrieved this}

record:

- It checked for the presence of a 776|w. It was found, so it searched for a match of the same content [46593967] in an 035|a field

- When the match was found in the 035|a field, it created a hyperlink in the OPAC

- Both records have both 035|a and 776|w, so the process works in reverse, or reciprocal links. 


\section{Bib Linking Benefits}

Things are clearer to our patrons in the OPAC display by providing seamless transport between :

- print, microfilm, and electronic formats

- print and electronic serial versions

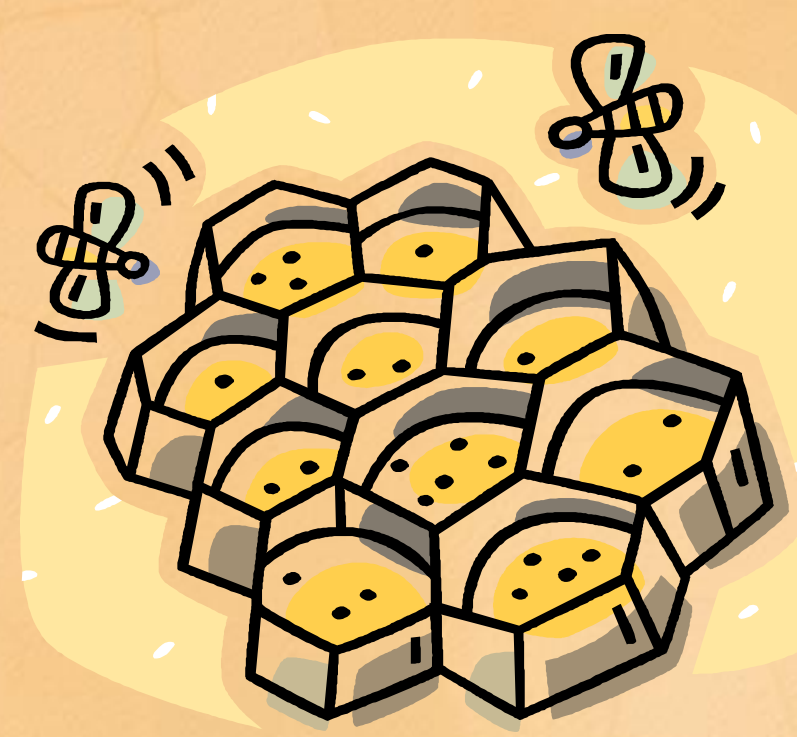




\section{Print \\ Display \\ for book}

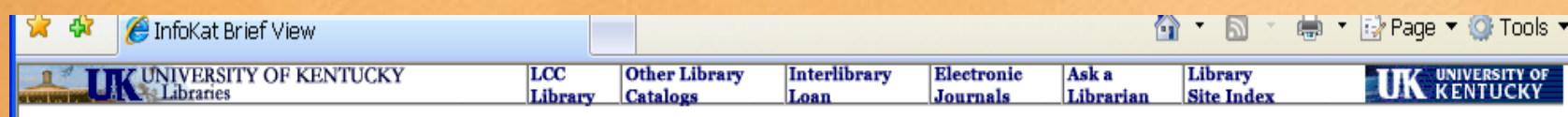

UK

INFOKAT

- UnIVERSITY OF KENTUCKY LibraRIES ONLINE CATALOg \& GATEWAY

Beginning May 10 th Library Link has selocated to Little Fine Arts Library and will retum to the 108 POT on August 17th.

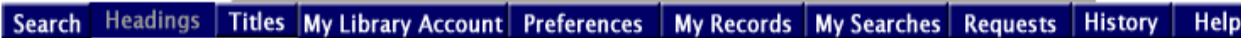

Exit

Database Name: University of Kentucky Libraries

Search Request: Left Anchored Title = wehmans

Search Results: Displaying 1 of 3 entries

Next)

\begin{tabular}{|l|l|l|}
\hline Brief View & Full View & MARC Format \\
\hline
\end{tabular}

Wehman's book on the adventures of Daniel Boone.

Title: Wehman's book on the adventures of Daniel Boone.

Publisher: New York: Henry J. Wehman, [18--?]

Description: 48 p. : ill. ; $19 \mathrm{~cm}$.

Other Format(s): \# Full Title

[1] Wehman's book on the adventures of Daniel Boone [microform]

[2] Wehman's book on the adventures of Daniel Boone [electronic resource]

Location: Spec Coll Library - X Collections

Call Number: 813 D5926 W423d

Status: No information available

Next 


\section{Microfilm}

Display

(Solinet

grant

project)

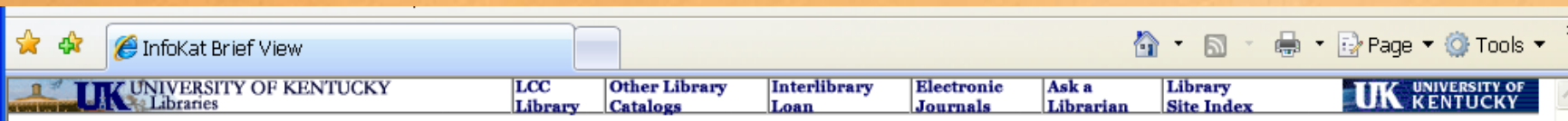

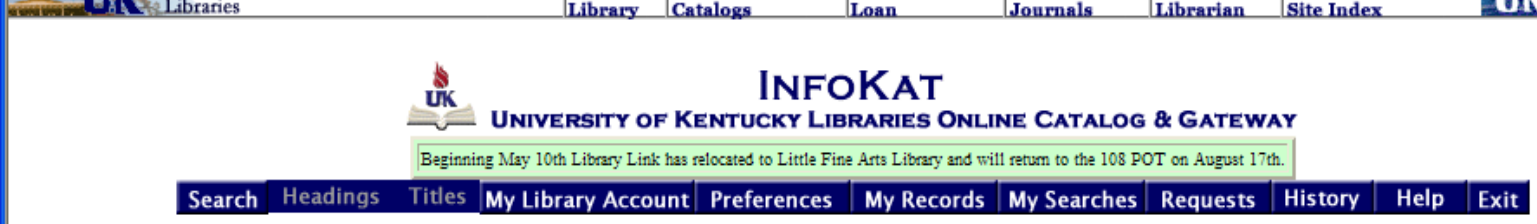

Database Name: University of Kentucky Libraries

Search Request: Left Anchored Title = wehmans

Search Results: Displaying 1 of 2 entries

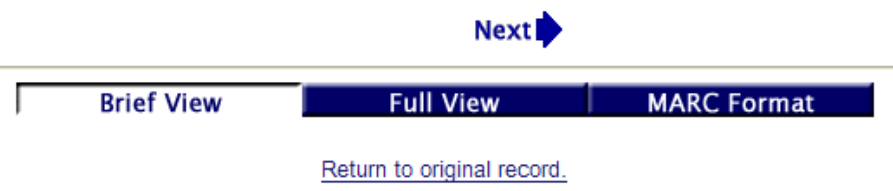

Wehman's book on the adventures of Daniel Boone

Title: Wehman's book on the adventures of Daniel Boone [microform]

Publisher: New York : Henry J. Wehman, [18--?]

Description: 48 p. : ill. ; $19 \mathrm{~cm}$.

Other Format(s): \# Full Title

[1] Wehman's book on the adventures of Daniel Boone.

[2] Wehman's book on the adventures of Daniel Boone [electronic resource]

Location: Young Library - Periodicals Desk Microfilm

Call Number: B 92-77

Status: No information available

Next $\vec{\gamma}$ 


\section{Electronic}

\section{Display}

(Beyond

\section{the Shelf}

grant

project)

\begin{tabular}{|c|c|c|c|}
\hline th the Infokat Brief View & Q & & 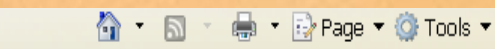 \\
\hline 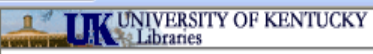 & 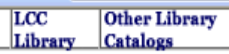 & \begin{tabular}{|l|l|} 
Interlibrary \\
Loan
\end{tabular} & \begin{tabular}{|l|l|} 
Ask a & Library \\
Librarian & Site Index \\
\end{tabular} \\
\hline
\end{tabular}

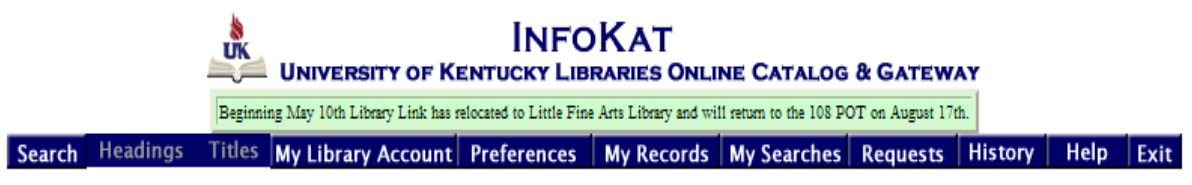

Database Name: University of Kentucky Libraries

Search Request: Left Anchored Title = wehmans

Search Results: Displaying 2 of 2 entries

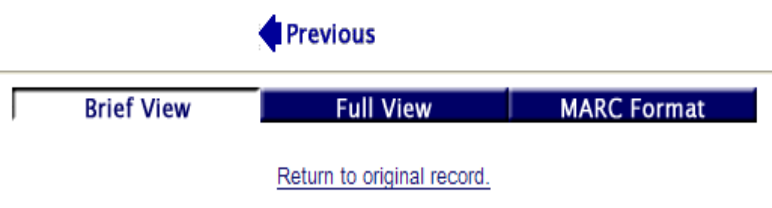

Wehman's book on the adventures of Daniel Boone

Title: Wehman's book on the adventures of Daniel Boone [electronic resource]

Publisher: New York : Henry J. Wehman, [18--?]

Description: 48 p. : ill. ; $19 \mathrm{~cm}$.

Includes: Computer File

Internet Access: http://purl.oclc.org/KUK/KDL/B92-77-27211874

Other Format(s): \# Full Title

[1] Wehman's book on the adventures of Daniel Boone.

Location: INTERNET

Call Number: See Internet Access

Status: No information available 


\section{Digital}

\section{Image}

\section{-}

in

Kentuckiana

Digital

Library

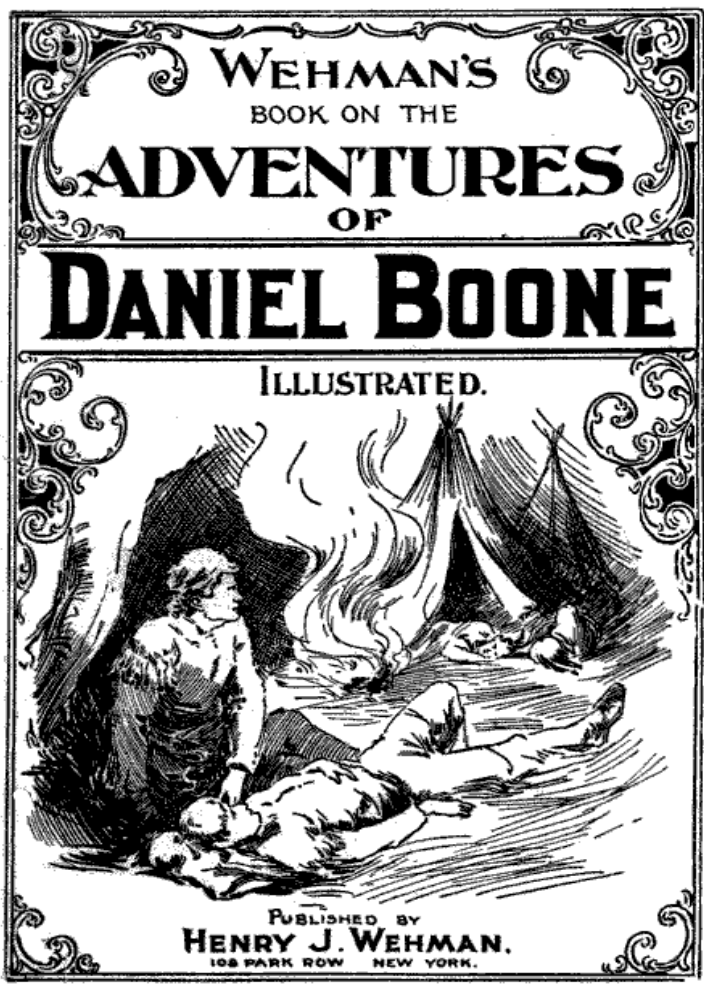




\section{Future possibilities}

- ISSN

- ISBN

- parent/child relationships

- earlier/later serial titles

- any relationship that can be defined 


\section{Bib linking problems}

- Multiple matches

\section{within the same record}

- Different Owning Library

- Empty links from suppressed records

- Invalid matches

- Failure to match 


\section{Clean up}

\section{Access \\ Reports to identify the problems}

TSK--Bib_Index for selected BIDs-776W.xls--Only 2006 and early 2007 action dates

\begin{tabular}{|c|c|c|c|c|c|c|c|c|}
\hline BIB_ID & INDEX_CODE & NORMAL_HEADING & DISF & PLAY_HEADING & TITLE & ISSN & $\mathrm{LCCN}$ & ACTION_DATE \\
\hline 1768370 & $776 \mathrm{~W}$ & 00008009 & (DLC) & 00008009 & Ecological indicators for the nation [computer file] / & & 00008009 & $10 / 20 / 2006 \quad 14: 45$ \\
\hline 1760767 & $776 \mathrm{~W}$ & 00008064 & (DLC) & 00008064 & Voices of a new Chicana/o history [computer file]/ & & 00008064 & 10/19/2006 17:15 \\
\hline 1850637 & $776 \mathrm{~W}$ & 00008068 & (DLC) & 00008068 & Separate spheres no more [electronic resource] : & & & $10 / 25 / 20068: 33$ \\
\hline 1847362 & $776 \mathrm{~W}$ & 00008103 & (DLC) & 00008103 & Inquiry and the National Science Education & & & $10 / 24 / 20067: 55$ \\
\hline 1847388 & $776 \mathrm{~W}$ & 00008122 & (DLC) & 00008122 & Nouvelle France [electronic resource] : the making & & & $10 / 24 / 20067: 56$ \\
\hline 1878719 & $776 \mathrm{~W}$ & 00008147 & (DLC) & 00008147 & Journey of Navajo Oshley [electronic resource] : an & & & $10 / 25 / 20069: 53$ \\
\hline 2470344 & $776 \mathrm{~W}$ & 00008194 & (DLC) & 00008194 & Mentor's guide [electronic resource] : facilitating & & & 10/31/2006 11:14 \\
\hline 1768409 & $776 \mathrm{~W}$ & 00008199 & $(\mathrm{DLC}) \mathrm{C}$ & 00008199 & Surviving supply chain integration [computer file] : & & 00008199 & $10 / 20 / 200614: 55$ \\
\hline 1851201 & $776 \mathrm{~W}$ & 00008214 & (DLC) & 00008214 & From southern wrongs to civil rights [electronic & & & $10 / 25 / 20068: 45$ \\
\hline 1849923 & $776 \mathrm{~W}$ & 00008231 & (DLC) & 00008231 & Crowded airwaves [electronic resource] : campaign & & & $10 / 25 / 20068: 18$ \\
\hline 1851465 & $776 \mathrm{~W}$ & 00008273 & (DLC) & 00008273 & Traits of champions : the secrets to championship & & & $10 / 25 / 20068: 52$ \\
\hline 1850320 & $776 \mathrm{~W}$ & 00008278 & (DLC) & 00008278 & Pioneering organizations [electronic resource] : the & & & 10/25/2006 8:26 \\
\hline 1768886 & $776 \mathrm{~W}$ & 00008287 & (DLC) & 00008287 & Some babies grow up to be cowboys [computer file] & & 00008287 & $10 / 20 / 2006 \quad 16: 49$ \\
\hline 1847369 & $776 \mathrm{~W}$ & 00008316 & (DLC) & 00008316 & Grading the nation's report card [electronic resource] & & & $10 / 24 / 20067: 55$ \\
\hline 1849241 & $776 \mathrm{~W}$ & 00008345 & (DLC) & 00008345 & Power within [electronic resource] : the five & & & 10/25/2006 8:04 \\
\hline 1849310 & $776 \mathrm{~W}$ & 00008352 & (DLC) & 00008352 & Counting on the census? [electronic resource] : & & & $10 / 25 / 20068: 05$ \\
\hline 1850396 & $776 \mathrm{~W}$ & 00008355 & (DLC) & 00008355 & All the lost girls [electronic resource] : confessions of & & & $10 / 25 / 20068: 28$ \\
\hline 1848810 & $776 \mathrm{~W}$ & 00008404 & (DLC) & 00008404 & Bypass [electronic resource] : a memoir / by Joseph & & & 10/24/2006 8:16 \\
\hline 1849526 & $776 \mathrm{~W}$ & 00008415 & (DLC) & 00008415 & Dollars for terror [electronic resource] : the United & & & $10 / 25 / 20068: 10$ \\
\hline 1847881 & $776 \mathrm{~W}$ & 00008433 & (DLC) & 00008433 & Perverse spectators [electronic resource] : the & & & 10/24/2006 8:02 \\
\hline 1848971 & $776 \mathrm{~W}$ & 00008435 & (DLC) & 00008435 & Arrested adulthood [electronic resource] : the & & & 10/24/2006 8:19 \\
\hline 1849456 & $776 \mathrm{~W}$ & 00008523 & (DLC) & 00008523 & Australia [electronic resource] / by Shirley W. Gray. & & & 10/25/2006 8:08 \\
\hline 1849732 & $776 \mathrm{~W}$ & 00008524 & (DLC) & 00008524 & Brazil [electronic resource] / by Shirley W. Gray : & & & 10/25/2006 8:14 \\
\hline 1849342 & $776 \mathrm{~W}$ & 00008525 & (DLC) & 00008525 & China [electronic resource] / by Susan Sinnott. & & & 10/25/2006 8:06 \\
\hline 1849542 & $776 \mathrm{~W}$ & 00008526 & (DLC) & 00008526 & Japan [electronic resource] / by Susan Sinnott. & & & 10/25/2006 8:10 \\
\hline 1849533 & $776 \mathrm{~W}$ & 00008527 & (DLC) & 00008527 & Mexico [electronic resource] / by Shirley W. Gray. & & & 10/25/2006 8:10 \\
\hline 1849513 & $776 \mathrm{~W}$ & 00008528 & (DLC) & 00008528 & Coral reefs [electronic resource] / by Susan H. Gray. & & & 10/25/20068:09 \\
\hline 1849521 & $776 \mathrm{~W}$ & 00008529 & (DLC) & 00008529 & Deserts [electronic resource] / by Susan H. Gray. & & & 10/25/20068:10 \\
\hline 1849474 & $776 \mathrm{~W}$ & 00008530 & (DLC) & 00008530 & Grasslands [electronic resource] / by Susan H. Gray. & & & $10 / 25 / 20068: 09$ \\
\hline 1849462 & $776 \mathrm{~W}$ & 00008531 & (DLC) & 00008531 & Mountains [electronic resource] / by Susan H. Gray. & & & 10/25/2006 8:08 \\
\hline 1849481 & $776 \mathrm{~W}$ & 00008532 & (DLC) & 00008532 & Oceans [electronic resource] / by Susan H. Gray. & & & 10/25/2006 8:09 \\
\hline 1849469 & $776 \mathrm{~W}$ & 00008534 & (DLC) & 00008534 & Rain forests [electronic resource] / by Shirley W. & & & 10/25/2006 8:09 \\
\hline 1849501 & $776 \mathrm{~W}$ & 00008535 & (DLC) & 00008535 & Tundra [electronic resource] / by Susan H. Gray. & & & 10/25/2006 8:09 \\
\hline 1849489 & $776 \mathrm{~W}$ & 00008536 & (DLC) & 00008536 & Wetlands [electronic resource] / by Shirley W. Gray. & & & 10/25/2006 8:09 \\
\hline 2473058 & $776 \mathrm{~W}$ & 00008544 & (DLC) & 00008544 & Understanding James Welch [electronic resource] / & & & $11 / 1 / 2006$ 15:57 \\
\hline 1849565 & $776 \mathrm{~W}$ & 00008556 & (DLC) & 00008556 & Canada [electronic resource] / by Shirley W. Gray. & & & 10/25/2006 8:10 \\
\hline 1851147 & $776 \mathrm{~W}$ & 00008590 & (DLC) & 00008590 & Turning lead to gold [electronic resource] : the & & & $10 / 25 / 20068: 44$ \\
\hline 1767386 & $776 \mathrm{~W}$ & 00008630 & (DLC) & 00008630 & Aging mind [computer fle] : opportunities in & & 00008630 & $10 / 20 / 2006 \quad 12: 23$ \\
\hline 1849576 & $776 \mathrm{~W}$ & 00008669 & (DLC) & 00008669 & Boston Tea Party [electronic resource] / by Michael & & & 10/25/2006 8:11 \\
\hline 1849554 & $776 \mathrm{~W}$ & 00008670 & (DLC) & 00008670 & California Gold Rush [electronic resource] / by Jean & & & 10/25/2006 8:10 \\
\hline
\end{tabular}




\section{So what else is left?}

- Maintenance

- Minimal regular maintenance

- Suppressed records need to suppress the 776 field

- If you remove one half of the linked pair, the link disappears

- Ongoing

- Routine workflow during cataloging

- Verifying 776 links as records are added 


\section{Ongoing procedures}

- Cancelling print, subscribing to electronic

- Standardizing cancellation notes

Print subscription cancelled after [e.g. v.50 (2008)]

- New e-subscriptions

- Continuing clean-up

- Storing print backfiles 


\section{Copy Cataloging}

- Choose matching record based on title, ISSN, publication dates, format/GMD. Choose CONSER authenticated record whenever possible, identifiable by presence of 042 field.

- Once the record has been identified, add the 099 and 506 fields to the record

- In Voyager, add the 856 link to SFX: SFX URL + ISSN, or the SFX URL + journal title; ISSN or Journal title will need to be copied and pasted into the URL

- Delete extraneous 856 fields

- With the record on screen, review the record closely. It should have the following elements:

Form: $s$

$006 \mathrm{~m} d$ (for computer format)

007 c lb r |d c le n (for remote access computer file)

022 |a electronic ISSN ly Paper ISSN (if available)

099 SEE Internet Access

130 Uniform title with qualifier (Online) (if this is an electronic version of a print)

245 |h [electronic resource]

500 Title from title screen (viewed on date)

538 Mode of Access: World Wide Web

506 Restricted to subscribers.

530 Also available in a paper version. (if available)

6xx At least one LC subject heading

7761 |t title of paper version |x [ISSN] /w (OCoLC) (If available)

85640 |u URL for SFX link 


\section{The Future}

- Maybe ERM

- Next Gen Catalog/OPAC

- More backfiles

- More clean-up, more storage

- Incorporating CONSER Standard Record

- Reducing duplicate effort 


\begin{tabular}{|c|c|c|c|c|c|c|c|}
\hline$\Leftrightarrow(\theta)$ & () http://ukty-mt.iii.com/iii/encore/search/C\%7CSabacus $\% 7$ Corightresult\%7Cu1? lang=eng\&suite=def & $\checkmark$ & $\$ 4$ & $\mathrm{X}$ & Google & $\rho$ & - \\
\hline
\end{tabular}

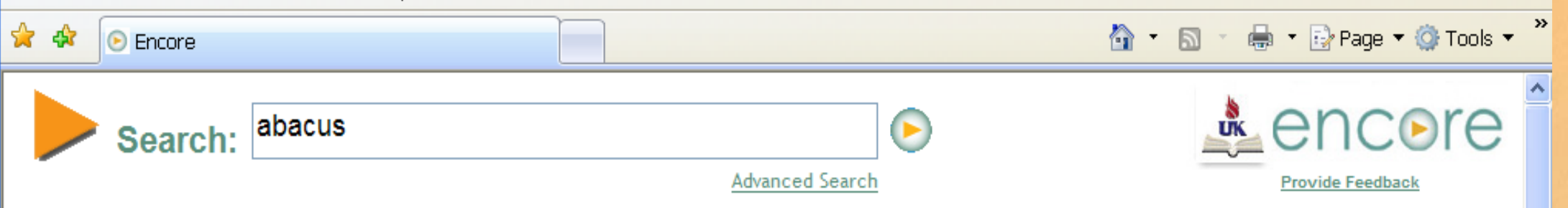

\section{Refine by:}

-SEARCH FOUND IN

Title (25)

Subject (5)

Author (1)

-FORMAT

PRINTED MATL (44)

-COLLECTION

INTERNET Resources (5)

Serials (2)

Wiliam T. Young Library (20)

Medical Center Library (1)

Law Library (3)

+ more

- Language

English (40)

Latin (3)

German (2)

-PUBlish Date

2006 (2)

2005 (2)

2002 (2)

2001 (4)

2000 (3)

+ more

\section{Searched: abacus (1-25 of 44)}

Sorted by Relevance | Title | Date $\rightarrow \square \square \square(1$ - 16) Most Relevant

\section{Abacus}

[Sydney, N.S.W.] : Sydney University Press, 1965 -

-Show library holdings

Location: Young Library - Periodicals (2nd \& 3rd floors)

Call Number: HF5601.A11

Holdings: v.1(1965)-v.42(2006)

1 Show location, call number, and availability

\section{Abacus [electronic resource]}

[Oxford] : Blackwell Publishers

Show library holdings

1 Show location, call number, and availability

\section{$\checkmark$ Get Text GUR}

From abacus to Zeus : a handbook of art history

Pierce, James Smith

Upper Saddle River, N.J. : Prentice Hall, c2001.

11 Show location, call number, and availability
2001

$1 \underline{2}$ next

1965
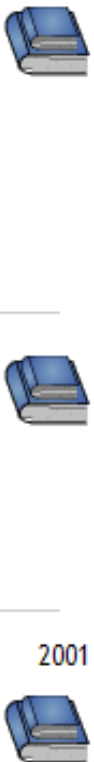

$\underline{\text { Table of }}$

\section{Recently Added:}

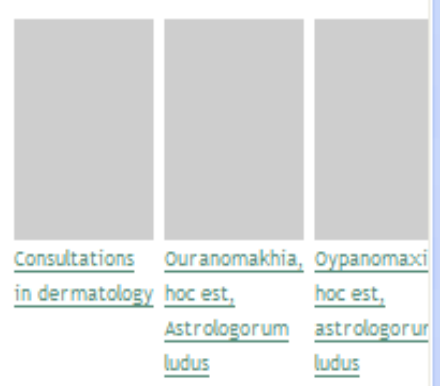

Refine by Tag:

\section{abacus} accounting antitrust law

\section{art dermatology}

electronic books

finance japan

korea math

mathematics 


\title{
Discussion/Questions?
}

\section{Marsha Seamans}

\section{Marsha.Seamans@uky.edu}

\author{
Nancy Lewis \\ Nancy.Lewis@uky.edu
}

